\title{
Dynamics of Replication and Nuclear Localization of the B Chromosome in Kidney Tissue Cells in Astyanax scabripinnis (Teleostei: Characidae)
}

\author{
Zelinda Schemczssen-Graeff, ${ }^{1}$ Patrícia Barbosa, ${ }^{2}$ Jonathan Pena Castro, ${ }^{2}$ Maelin da Silva, ${ }^{1}$ \\ Mara Cristina de Almeida, ${ }^{1}$ Orlando Moreira-Filho, ${ }^{1,2}$ and Roberto Ferreira Artoni ${ }^{1,2}$
}

\begin{abstract}
B chromosomes are extra genomic compounds found in different taxonomic groups, including plants and animals. Obtaining patterns of resolutive chromosomal bands is necessary to understand the nuclear organization, variability and nature of B chromosome chromatin and possible transcriptional regions. In this study, we analyzed 35 Astyanax scabripinnis specimens sampled from Fazenda Lavrinha, a stream in the Paraíba do Sul river basin, Brazil. Through the incorporation of the thymidine analog 5'-bromo-2'-deoxyuridine (5-BrdU) in vivo, it was possible to recognize the replicating regions of the $\mathrm{B}$ chromosome at the beginning of the $\mathrm{S}$ phase, differentially characterized in relationship to the regions of late replication. In this perspective, it is possible to suggest that the B chromosome of this species possesses a territory and the chromatin accessible for transcription, especially in the light (i.e., early replicating) bands (p1.1; p1.3; and p2.1 and q1.1, q1.3, q2.1, and q2.2). The latereplicating regions are corresponding to the blocks of constitutive heterochromatin. They show a preferential accumulation of satellite DNA As51. By the use of the fluorochrome chromomycin A3 (CMA3), it was possible to identify GC-rich chromosomal regions, corresponding to late-replicating parts of genome, confirming the revealed data by the replication banding and C-banding. In addition, the analysis by confocal microscopy in kidney cells indicates the location of a peripheral anchorage of this chromosome in the nuclear lamina, reinforcing the idea of downregulation of the associated regions.
\end{abstract}

Keywords: DNA replication, 3D FISH, chromosome banding, chromosome territories, confocal microscopy

\section{Introduction}

B CHROMOSOMES ARE extra genomic compounds occurring in different taxonomic groups, including plants and animals, ${ }^{1,2}$ Since their discovery in the beginning of the 20th century by Wilson, ${ }^{3} \mathrm{~B}$ chromosomes in organisms have been extensively investigated. ${ }^{4-7}$ Recent studies have focused on the evolution and biology of B chromosomes, highlighting the occurrence of genes on these extra genomic elements (revisited in Houben et l. $^{2}$ ).

In Neotropical fishes, $4 \%$ of the more than 1000 species with known karyotypes have B chromosomes. 8 From these, seven species belong to the genus Astyanax, namely ${ }^{10}$ A. fasciatus, A. schubarti, ${ }^{11}$ A. altiparanae, ${ }^{12}$ A. bockmanni, ${ }^{13}$ A. goyacensis, ${ }^{14}$ A. paranae, ${ }^{15}$ and A. scabripinnis. ${ }^{10,16}$
In A. scabripinnis, the origin of the B macrochromosomes was initially attributed to events of meiotic nondisjunction based on the comparative inferences from the size and morphology of these B chromosomes when compared to the first pair of standard A chromosomes. ${ }^{10}$

Recently, the more accepted theory assumes that the B chromosome of A. scabripinnis had originated through an emergence of isochromosomes from the acrocentric pair $24{ }^{17}$ This hypothesis is based on the presence of an interstitial heterochromatic band in the long arm of this chromosome pair, displaying an equilocal position on both arms of the $\mathrm{B}$ chromosome, in addition to a strongly marked band on the two arms of the B chromosome. ${ }^{17}$ This evidence is corroborated by the chromosomal location, of As51 satellite DNA after fluorescence in situ hybridization (FISH), ${ }^{18}$ and the chromosome pairing during meiosis. ${ }^{19}$

\footnotetext{
${ }^{1}$ Programa de Pós-Graduação em Biologia Evolutiva, Laboratório de Genética Evolutiva, Universidade Estadual de Ponta Grossa, Ponta Grossa, Paraná, Brazil.

${ }^{2}$ Programa de Pós-Graduação em Genética Evolutiva e Biologia Molecular, Laboratório de Citogenética de Peixes, Universidade Federal de São Carlos, São Carlos, São Paulo, Brazil.
} 
Populations of A. scabripinnis from the Atlantic forest on the Brazilian coast (Campos do Jordão, São Paulo) have attracted special attention in evolutionary studies. This region is $2000 \mathrm{~m}$ in altitude and the populations live isolated at the headwaters of small streams, ${ }^{16}$ many of them with the presence of the B chromosome (reviewed by Moreira-Filho et al. ${ }^{20}$ ).

One of the central problems of the comparative cytogenetics in fishes is the difficulty to obtain resolute patterns of longitudinal chromosomal bands. ${ }^{21}$ An alternative is to obtain the replication bands by the incorporation of the base analogs during cellular division, ${ }^{22}$ which is based on the incorporation of the thymidine analog 5'-bromo-2'-deoxyuridine (5-BrdU). It can be a strategy to delimit the regions with a possible transcriptional activity on B chromosomes.

Using the replication banding method, Maistro et $a l^{23}$ demonstrated that the $\mathrm{B}$ chromosome of A. scabripinnis possess a late-replicating pattern due principally to its heterochromatic nature. ${ }^{10,17}$ Nonetheless, the replication timing in the whole chromosome and intercalary regions still unclear. In addition, the nature of the B-chromosome chromatin is an unresolved question, despite the mapping of microsatellite sequences. $^{24}$

The chromosomes occupy separated territories in the interphase nucleus of eukaryotic cells. ${ }^{25}$ A co-regulation model proposed that more centralized regions in the nucleus are enrichment with transcriptionally active genes while more periphery regions content inactive regions of the genome. ${ }^{26}$

On the other hand, new models of genetic regulation within the interphase nucleus have been proposed. The definition of maps with high resolution of the chromatin interaction allows us to identify the so-called topologically associated domains (TADs), which are based and identified according to the expression activity, replication timing, or the epigenetic landscape proteins associated with them. In addition, other chromosome domains can be defined by the interaction between neighboring regions, such as laminaassociated domains (LADs), defined by chromosomal interactions with a nuclear lamina and their a correlation with low gene expression and late replication timing. Thus, such mechanisms have been understood and identified with respect to cell type-specific gene expression. ${ }^{27}$ Genome-wide data from different organisms are increasingly available. The interpretation of this information against 3D conformations of the chromosomes in the nucleus and their territories, with an effect on the biology of organisms, will be the biggest challenge in the coming years. On the other hand, the nuclear territory of B chromosomes, especially in fishes, is still completely lacking.

Thus, this study aims to investigate whether the B chromosome of $A$. scabripinnis possesses transcriptional regions, using the replication pattern, the chromatin nature, and their distribution in the interphase nucleus of kidney cells.

\section{Materials and Methods}

\section{Biologic samples}

We used 35 A. scabripinnis specimens from Fazenda Lavrinha, a stream in the Paraíba do Sul river basin (S 22 $43^{\prime} 09,6^{\prime \prime}$ I WO $\left.45^{\circ} 25^{\prime} 38,5^{\prime \prime}\right)$. The specimens were identified and received a voucher number from Núcleo de Pesquisas em Limnologia, Ictiologia e Aquicultura of Universidade Estadual de Maringá
(NUP no. 17482). This research had the authorization from the ethics committee of the State University of Ponta Grossa (Protocol $N^{\circ}$ 04509/08) and license to collect biological material by Instituto Brasileiro do Meio Ambiente e dos Recursos Naturais Renováveis (IBAMA) under n¹5115-1.

\section{Chromosome preparations}

Mitotic chromosomes were obtained from the kidney cells by direct preparation described in Bertollo et al. ${ }^{28}$ and shortterm culture according to Fenocchio et al. ${ }^{29}$ The incorporation of thymidine analog 5-BrdU and the revelation of bands followed the established protocol of Giles et al. ${ }^{30}$ The constitutive heterochromatin was performed by the C-banding method. ${ }^{31}$ For staining with the base-specific fluorochromes chromomycin A3 (CMA3) and 4',6-diamidino-2phenylindole (DAPI), the protocol described by Schweizer ${ }^{32}$ was followed.

\section{Preparation of cells for confocal microscopy}

Part of the kidney cell suspension was resuspended in fetal bovine serum (Sigma-Aldrich Brasil Ltda) and dripped onto a previously polysin-coated slide $(10 \mathrm{mg} / \mathrm{mL})$, and left in the oven at $37^{\circ} \mathrm{C}$ for $1 \mathrm{~h}$. The cells were drained of excess fetal bovine serum and washed in $0.3 \times$ phosphate-buffered saline buffer for $40 \mathrm{~s}$. Subsequently, the fixation in $4 \% \mathrm{w} / \mathrm{v}$ paraformaldehyde took place. After this procedure, the slides could be used for FISH procedures. The 3D images were captured using a Leica TCS SP8 laser scanning confocal microscope with LAS AF SP8 3D visualization software, with $2 \mu \mathrm{m}$ capture cut.

\section{Fluorescent in situ hybridization}

The As51 satellite DNA described by Mestriner et al. ${ }^{18}$ was obtained from the nuclear DNA of A. scabripinnis using the primers Fw 5'-GGTCAAAAAGTCGAAAAA-3' and Rv $5^{\prime}$-GTACCAATGGTAGACCAA- $3^{\prime}$ in 35 cycles in the Eppendorf Mastercycler $1 \mathrm{~min}$ at $95^{\circ} \mathrm{C}, 45 \mathrm{~s}$ at $56^{\circ} \mathrm{C}, 1 \mathrm{~min}$ at $72^{\circ} \mathrm{C}$, and $5 \mathrm{~min}$ at $72^{\circ} \mathrm{C}$. The $A s 51$ satellite DNA probe was marked by the nick translation using biotin 14-dATP (Bionick Labeling System; Invitrogen-Thermo Fisher Scientific, $\mathrm{SP}$, Brazil) in dry bath Loccus Biotecnologia TM (1 h and $30 \mathrm{~min}$ at $15^{\circ} \mathrm{C}$ after $15 \mathrm{~min}$ at $65^{\circ} \mathrm{C}$ ).

FISH was performed using the protocol of Pinkel et al. ${ }^{33}$ with modifications according to Vicari et al. ${ }^{34}$ The protocol has been adapted for hybridization in high stringency conditions $(2.5 \mathrm{ng} / \mathrm{mL}$ probe, $50 \%$ deionized formamide, $10 \%$ dextran sulfate, and $2 \times$ buffer saline sodium citrate [SSC] at $37^{\circ} \mathrm{C}$ overnight). After the hybridization, the slides were washed in a $50 \%$ formamide $/ 0.2 \times \mathrm{SSC}$ solution at $42^{\circ} \mathrm{C}$ for $20 \mathrm{~min}$ and $4 \times \mathrm{SSC} / 0.05 \%$ Tween at room temperature for $10 \mathrm{~min}$. The signal detection was performed with Streptavidin conjugated with Alexa Fluor ${ }^{\circledR} 488$ (Thermo Fisher Scientific). The chromosomes were counterstained with DAPI $(0.2 \mu \mathrm{g} / \mathrm{mL})$ diluted in antifade solution $\left(\right.$ Fluka $\left.^{\mathrm{TM}}\right)$.

Chromosomes and nuclei were analyzed under an epifluorescence microscopy Zeiss AxioCam MRm with software ZEN pro 2011 (Carl Zeiss ${ }^{\circledR}$ ) and confocal microscopy Leica TCS SP8 with software LAS AF SP8 3D visualization. 
The best metaphases were photographed and the karyotype was organized in Photoshop, version CC 2015. The diagram was assembled with the Corel Draw v. X7.

\section{Results}

The conventional analysis of the karyotype of A. scabripinnis evidenced a karyotype macrostructure with a presence of one polymorphic metacentric B chromosome in the population. These data validate previous studies with specimens from the population of the Fazenda Lavrinha stream with $2 n=51$ chromosomes $(6 \mathrm{~m}+22 \mathrm{sm}+10 \mathrm{st}+12 \mathrm{a}+1 \mathrm{Bm})$, without an occurrence of morphologically differentiated sex chromosomes. $^{35}$

The cells treated with 5-BrdU showed a banding pattern corresponding with a heterogeneous replication timing on the chromosomes of A. scabripinnis (Fig. 1). The B chromosome possessed a longitudinal banding pattern compatible with the early replication (bright bands), replicating (p1.3; p1.1; p2.2 e q1.3; q1.1; q2.3; q2.1), and also with late replication (p2.1; p1.2 e q1.2; q2.4; q2.2) (Fig. 2).

The late-replicating regions were coincident with the blocks of constitutive heterochromatin and preferential localization of repetitive sequences As51 satellite DNA (Fig. 2). The fluorochrome CMA3 allowed us to visualize $\mathrm{CG}$-rich regions with high contrast, coincident with late-replicating regions (Fig. 2 and Supplementary Fig. S1). The C-banding method showed heterochromatic region patterns similar to previous studies in Astyanax species. ${ }^{10,17}$

The utilization of a confocal laser scanning microscopy associated the FISH-based chromosomal mapping of As51 satDNA (Fig. 3a, b), identified that this sequence occupies a peripheral domain in the interphase nucleus of kidney cells (Fig. 3c).

\section{Discussion}

In this study, we obtained a replication banding pattern through in vivo treatment with 5-BrdU (6-7 h), which enabled more precise identification of homologs into 25 pairs and yielded multiple bands on the $\mathrm{B}$ chromosome. Previous studies revealed replication bands in $A$. paranae, ${ }^{23} A$. altiparanae, A. schubarti, A. fasciatus, and A. scabripinnis. ${ }^{36}$ However, in obtaining these markers by 5-BrdU, with intention of use for interspecific karyotype comparison, this marker fell into disuse in fishes, due to a lack of comparative patterns of these bands in identifying chromosomal homologies. ${ }^{22}$
Thus, new studies of $\mathrm{B}$ chromosomes using 5 -BrdU in some of these species have ceased, due to the dynamic nature of the band replication obtained with this methodology. We return to the subject in this work, performing an integrative analysis of the structure, replication dynamics, and potential functional regions of these supernumerary chromosomes.

In this study, we find regions corresponding to light and dark replication bands on the $\mathrm{B}$ chromosome of $A$. scabripinnis. The obtained pattern shows that this chromosome, although generally appearing completely heterochromatic, has a heterogeneous nature with regard to the chromatin composition. In addition, it can be inferred that the replication of this chromosome occurs at different stages of the $S$ phase of the cell cycle.

AT-rich regions are relatively underrepresented in opposite to GC-rich gene. ${ }^{37}$ With the fluorochrome CMA3, it was possible to evidence regions rich in $\mathrm{CG}$, and CMA3+ regions poor in genes, confirming what was identified by the incorporation of 5-BrdU and C-banding. Cristiano et al. ${ }^{38}$ found the same pattern for CMA3 in Melitoma segmentaria. Other bees have the same cytogenetic divergence as Melipona in relationship to heterochromatin content and have unique patterns of CMA3 accumulation, showing that heterochromatin is heterogeneous in relationship to its composition, with some blocks rich in AT-and others in CG pairs. ${ }^{39}$

Our results indicate that the $\mathrm{B}$ chromosome of $A$. scabripinnis has a chromosomal compartmentalization, reminiscent of isochores observed in mammals (Fig. 2), which are involved in genome compartmentalization and support the tissue-specific transcriptional regulation in all metazoa. ${ }^{40,41}$ In the yeast, Saccharomyces cerevisiae, some chromosomal regions replicate at different times, ${ }^{42,43}$ as well as in mammals and other eukaryotes. ${ }^{37}$

In this perspective, it is possible to suggest that the B chromosome of A. scabripinnis studied, herein, exhibits chromatin accessible for transcription, particularly in the light bands corresponding with early replication. Regardless to their possible origin, the chromosomal fragments that include gene sequences are potential components of any B chromosome and because there is a relaxed selective pressure over the genes and others sequence on the B chromosomes, evolutionarily newly formed B chromosomes must be richer in functional gene sequences than the evolutionarily older ones. ${ }^{39,44}$

The epigenetic marks 5-methylcytosine and 5-hydroxymethylcytosine in the B chromosome of Astatotilapia latifasciata, for example, may suggest it transcriptionally active

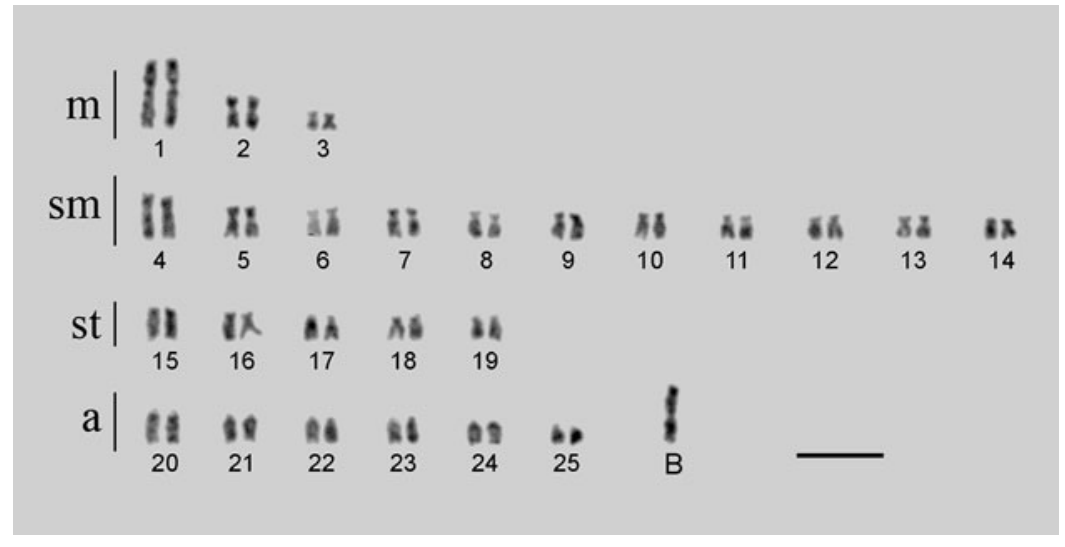

FIG. 1. Mitotic metaphase of Astyanax scabripinnis of the Fazenda Lavrinha stream, evidencing late-replicating bands by the incorporation of base analog 5-BrdU, highlighting the occurrence of a $\mathrm{B}$ chromosome. 5-BrdU, 5'-bromo-2'-deoxyuridine. 

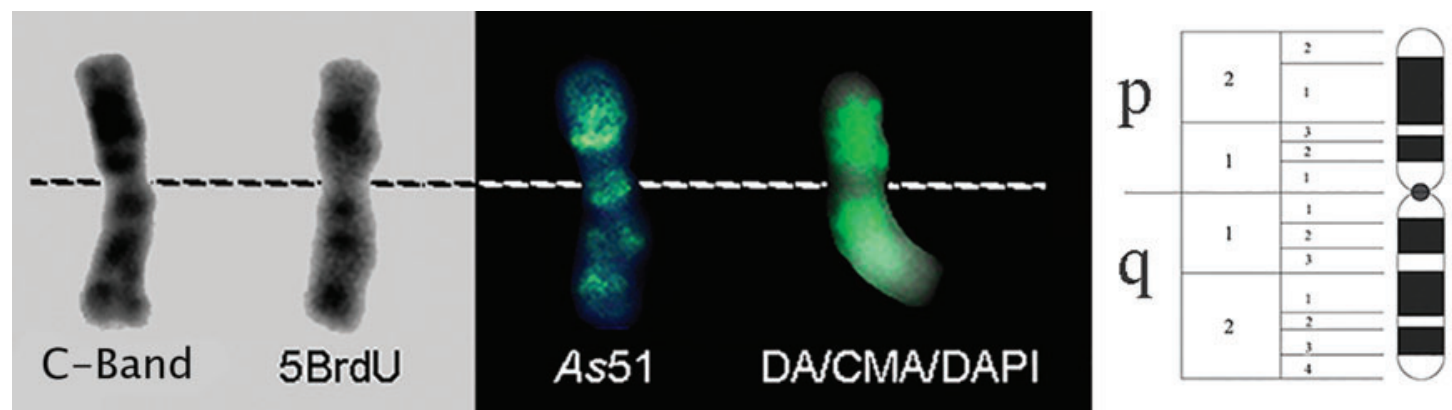

FIG. 2. B chromosome of A. scabripinnis from the Fazenda Lavrinha stream, submitted to different cytogenetic methods showing the structure, compartmentalization, and the chromatin nature. From left to right: regions of heterochromatin as revealed by C-banding; identification of replication banding pattern by 5-BrdU (with dark bands corresponding to regions of late replication); mapping with repetitive sequence As51; sequential staining with fluorochromes chromomycin and DAPI, for identification of CG-rich and AT-rich regions, respectively. On the right side, the compartmentalization idiogram showing longitudinal arrangement of replication bands on the B chromosome. DAPI, 4',6-diamidino-2-phenylindole. Color images are available online.

status. There is a correlation with the B chromosome presence and epigenetic effects. ${ }^{45}$

The regions marked by FISH with a probe corresponding to As51 satDNA coincided with the late-replicating heterochromatic regions on $\mathrm{A}$ chromosomes and it especially highlighted such regions on the B chromosome. Late- replicating regions were expected due to the heterochromatic nature of the $\mathrm{B}$ chromosome. Regions on the $\mathrm{B}$ chromosome marked by As51-specific probe are coincident with methylated sequences and accumulations of specific transposable elements (LINE and Tc1-Mariner), suggesting that these regions are being silenced in the genome (Barbosa et al.,
FIG. 3. Mitotic metaphase of A. scabripinnis from the Lavrinha Farm Stream, treated sequentially by replication banding, showing bands of late replication (a) and location of As51 sequences by FISH (b). Highlight arrow points on a $\mathrm{B}$ chromosome, which are accumulated with late-replicating regions (dark bands), corresponding with As51 hybridization signals (green). In (c) 3D analysis of the interphase nucleus of the kidney cell from A. scabripinnis under confocal microscopy, after FISH with As51 satellite DNA (green). FISH, fluorescence in situ hybridization. Color images are available online.
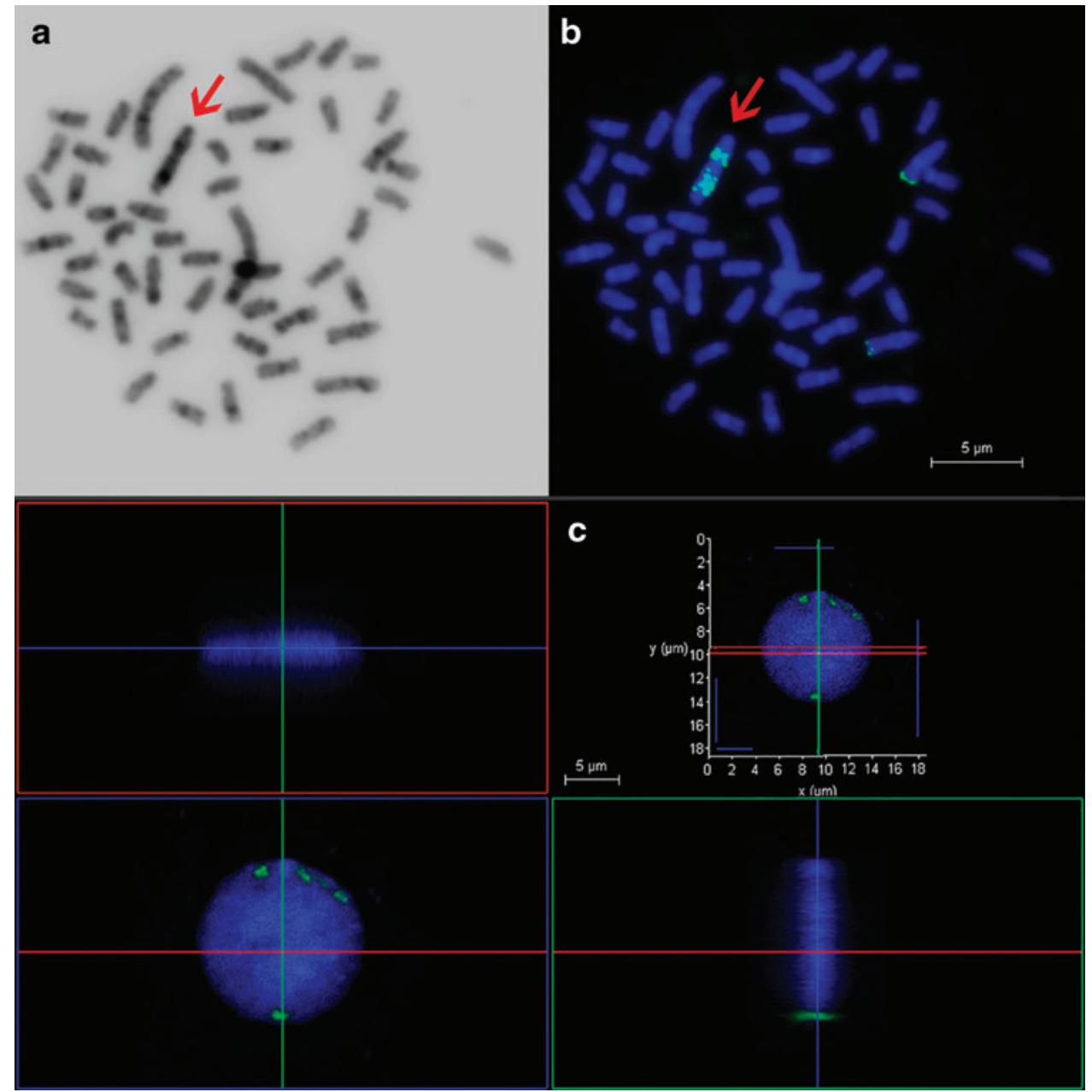
unpublished data). In addition, these regions are involved in the anchorage of this chromosome to the nuclear lamina, shown by confocal microscopy (Fig. 3c).

The sites where the chromosomes are anchored within the nucleus and where they form domains correspond directly to the association of chromatin with the nuclear lamina, thus forming LADs. ${ }^{25}$ These domains are involved in the downregulation of gene expression. Actively transcribed genes are usually found clustered in the center of interphase nucleus, while the inactive parts of the genome reside more toward the periphery of the nuclei. ${ }^{46}$ The repositioning hypothesis for the B chromosome of A. scabripinnis should be tested, given the heterogeneity of replication bands obtained here for this chromosome.

Hypomethylated centromeric regions of the corn B chromosome, for instance, become hypermethylated when this chromosome is transferred to oats. ${ }^{47}$ It is very likely that the regions corresponding to the early replicating pericentromeric bands (p1.1 and p1.3, hypomethylated and unlabelled by 5-methylcytosine according to Barbosa et al. unpublished data) may harbor genes related to centromeric function and maintenance of B chromosomes. Some studies have reported the presence of genes related to cell division in $\mathrm{B}$ chromosomes, ${ }^{48}$ to microtubules, structure of the kinetochore, and recombination in fishes. ${ }^{49}$

Moreira-Filho et al. ${ }^{20}$ reviewed the known information for B chromosome in A. scabripinnis, their presence, origin, frequency, and distribution in natural populations, and concluded that these approaches need further complementary studies, so that the presence and significance of B chromosomes for the species are better understood. One of the questions that still remains unresolved deals with the possible effects of the B chromosomes on their carriers. The mapping of euchromatic regions on the $\mathrm{B}$ chromosome of $A$. scabripinnis obtained here, as well as their location in interphase nuclei, is fundamental for the mapping of gene sequences and studies of the biological function of these enigmatic extra chromosomes.

\section{Disclosure Statement}

No competing financial interests exist.

\section{Funding Information}

The author Z.S.G. received a scholarship from the Coordenação de Aperfeiçoamento de Pessoal de Nível Superior (CAPES). This study received financial support from the Conselho Nacional de Desenvolvimento Científico e Tecnológico (CNPq). CNPq (Edital Universal 01/2016 - Process 407187/2016-2).

\section{Supplementary Material}

Supplementary Figure S1

\section{References}

1. Houben A, Jones N, Martins C, Trifonov V. Evolution, composition and regulation of supernumerary B chromosomes. Genes 2019;10:161.

2. Houben A, Banaei-Moghaddam AM, Klemme S, Timmis JN. Evolution and biology of supernumerary B chromosomes. Cell Mol Life Sci 2014;71:467-478.
3. Wilson CB. Additional notes on the development of the Argulidae, with description of a new species. Proc U S Natl Museum 1907;32:411-424.

4. Camacho JPM, Sharbel TF, Beukeboom LW. B-chromosome evolution. Philos Trans R Soc Lond B Biol Sci 2000;355: 163-178.

5. Jones RN. B chromosomes in plants. New Phytol 1995;131: 411-434.

6. Jone RN, Rees H. B Chromosomes. Academic Press, London, 1982.

7. Puertas MJ. Nature and evolution of B chromosomes in plants: a non-coding but information-rich part of plant genomes. Cytogenet Genome Res 2002;96:198-205.

8. Oliveira C, Almeida-Toledo LF, Foresti F. Karyotypic evolution in Neotropical fishes. In: Fish Cytogenetics. Pisano E, Ozouf-Costaz C, Foresti F, Kapoor BG (eds), pp. 111-164, CRC Press, Boca Raton, FL, 2007.

9. Carvalho RA, Martins-Santos IC, Dias AL. B chromosomes: an update about their occurrence in freshwater Neotropical fishes (Teleostei). J Fish Biol 2008;72:1907-1932.

10. Salvador LB, Moreira-Filho O. B chromosomes in Astyanax scabripinnis (Pisces, Characidae). Heredity (Edinb) 1992;69:50-56.

11. Moreira-Filho O, Fenocchio AS, Pastori MC, Bertollo LAC. Occurrence of a metacentric macrochromosome B in different species of the genus Astyanax (Pisces, Characidae, Tetragonopterinae). Cytologia (Tokyo) 2001;66:59-64.

12. Hashimoto DT, Gonçalves VR, Bortolozzi J, Foresti F, Porto-Foresti F. First report of a B chromosome in a natural population of Astyanax altiparanae (Characiformes, Characidae). Genet Mol Biol 2008;31:275-278.

13. Daniel SN, Hashimoto DT, Pansonato-Alves JC, Foresti F, Porto-Foresti F. Cytogenetic characterization of distinct B chromosomes in a population of the fish Astyanax bockmanni (Teleostei, Characiformes). Caryologia 2012;65: 229-233.

14. Dos Santos LP, Castro JP, Francisco CM, Vicari MR, de Almeida MC, Goll LG, et al. Cytogenetic analysis in the Neotropical fish Astyanax goyacensis Eigenmann, 1908 (Characidae, incertae sedis): karyotype description and occurrence of B microchromosomes. Mol Cytogenet 2013; 6:48.

15. Silva DMZ de A, Pansonato-Alves JC, Utsunomia R, Araya-Jaime C, Ruiz-Ruano FJ, Daniel SN, et al. Delimiting the origin of a $\mathrm{B}$ chromosome by FISH mapping, chromosome painting and DNA sequence analysis in Astyanax paranae (Teleostei, Characiformes). PLoS One 2014;9:e94896.

16. de Marco Ferro DA, Moreira-Filho O, Bertollo LAC. B chromosome polymorphism in the fish, Astyanax scabripinnis. Genetica 2003;119:147-53.

17. Vicente VE, Moreira-Filho O, Camacho JP. Sex-ratio distortion associated with the presence of a B chromosome in Astyanax scabripinnis (Teleostei, Characidae). Cytogenet Cell Genet 1996;74:70-75.

18. Mestriner C, Galetti PM, Valentini SR, Ruiz IRG, Abel LDS, Moreira-Filho O, et al. Structural and functional evidence that a B chromosome in the characid fish Astyanax scabripinnis is an isochromosome. Heredity (Edinb) 2000;85:1-9.

19. Vicari MR, de Mello Pistune HF, Castro JP, de Almeida MC, Bertollo LAC, Moreira-Filho O, et al. New insights on the origin of $\mathrm{B}$ chromosomes in Astyanax scabripinnis obtained by chromosome painting and FISH. Genetica 2011;139:1073-81. 
20. Moreira-Filho O, Galetti PM, Bertollo LAC. B chromosomes in the fish Astyanax scabripinnis (Characidae, Tetragonopterinae): an overview in natural populations. Cytogenet Genome Res 2004;106:230-234.

21. Artoni RF, Molina WF, Bertollo LAC, Galetti Junior PM. Heterochromatin analysis in the fish species Liposarcus anisitsi (siluriformes) and Leporinus elongatus (Characiformes). Genet Mol Biol 1999;22:39-44.

22. Daniel-Silva MFZ, Almeida-Toledo LF. Chromosome evolution in fish: BrdU replication patterns demonstrate chromosome homeologies in two species of the genus $A s$ tyanax. Cytogenet Genome Res 2005;109:497-501.

23. Maistro EL, Foresti F, Oliveira C. R- and G-band patterns in Astyanax scabripinnis paranae (Pisces, Characiformes, Characidae). Genet Mol Biol 1999;22:201-204.

24. Barbosa P, Leal EV, da Silva M, de Almeida MC, MoreiraFilho O, Artoni RF. Variability and evolutionary implications of repetitive DNA dynamics in genome of Astyanax scabripinnis (Teleostei, Characidae). Comp Cytogenet 2017;11:143-162.

25. Cremer T, Cremer C. Chromosome territories, nuclear architecture and gene regulation in mammalian cells. Nat Rev Genet 2001;2:292-301.

26. Schoenfelder S, Sexton T, Chakalova L, Cope NF, Horton A, Andrews S, et al. Preferential associations between coregulated genes reveal a transcriptional interactome in erythroid cells. Nat Genet 2010;42:53-61.

27. Gonzalez-Sandoval A, Gasser SM. On TADs and LADs: spatial control over gene expression. Trends Genet 2016; 10:1-11.

28. Bertollo LAC, Takahashi CS, Moreira-Filho O. Cytotaxonomic considerations on Hoplias lacerdae (Pisces, Erythrinidae). Braz J Genet 1978;1:103-120.

29. Fenocchio AS, Venere PC, Cesar ACG, Dias AL, Bertollo LAC. Short term culture from solid tissues of fishes. Caryologia 1991;44:161-166.

30. Giles V, Thode G, Alvarez MC. Early replication bands in two scorpion fishes, Scorpaena porcus and $S$. notata (order Scorpaeniformes). Cytogenet Cell Genet 1988;47:80-83.

31. Sumner AT. A simple technique for demonstrating centromeric heterochromatin. Exp Cell Res 1972;75:304-306.

32. Schweizer D. Simultaneous fluorescent staining of $R$ bands and specific heterochromatic regions (DA-DAPI bands) in human chromosomes. Cytogenet Cell Genet 1980;27:190-193.

33. Pinkel D, Straume T, Gray JW. Cytogenetic analysis using quantitative, high-sensitivity, fluorescence hybridization. Proc Natl Acad Sci U S A 1986;83:2934-2938.

34. Vicari MR, Nogaroto V, Noleto RB, Cestari MM, Cioffi MB, Almeida MC, et al. Satellite DNA and chromosomes in Neotropical fishes: methods, applications and perspectives. J Fish Biol 2010;76:1094-1116.

35. Barbosa P, de Oliveira LA, Pucci, MB, Santos MH, Moreira-Filho O, Vicari MR, et al. Identification and chromosome mapping of repetitive elements in the Astyanax scabripinnis (Teleostei: Characidae) species complex. Genetica 2015;143:55-62.

36. Daniel-Silva MFZ, Toledo LFDA. Chromosome R-banding pattern and conservation of a marker chromosome in four species, genus Astyanax (Characidae, Tetragonopterinae). Caryologia 2001;54:209-215.
37. Sumner AT. Chromosomes: Organization and Function. Wiley-Blackwell, Oxford, 2003.

38. Cristiano MP, Simoes TG, Lopes DM and Pompolo SG. Cytogenetics of Melitoma segmentaria (Fabricius, 1804) (Hymenoptera, Apidae) reveals differences in the characteristics of heterochromatin in bees. Comp Cytogenet 2014; 8:223-231.

39. Fernandes A, Werneck HA, Pompolo SG, Lopes DM. Evidence of separate karyotype evolutionary pathway in Euglossa orchid bees by cytogenetic analyses. An Acad Bras Ciênc 2013;85:937-944.

40. Tanay A, Cavalli G. Chromosomal domains: epigenetic contexts and functional implications of genomic compartmentalization. Curr Opin Genet Dev 2013;23:197-203.

41. Razin SV, Gavrilov AA, Vassetzky YS, Ulianov SV. Topologically-associating domains: gene warehouses adapted to serve transcriptional regulation. Transcription 2016;7:84-90.

42. Bickmore WA, Craig J. Chromosome Bands: Patterns in the Genome. R.G. Landes, Austin, 1997.

43. Brewer BJ, Diller JD, Friedman KL, Kolor KM, Raghuraman MK, Fangman WL. The topography of chromosome replication in yeast. Cold Spring Harb Symp Quant Biol 1993;58:425-434.

44. Banaei-Moghaddam AM, Martis MM, Macas J, Gundlach H, Himmelbach A, Altschmied L. Genes on B chromosomes: old questions revisited with new tools. Biochim Biophys Acta 2015;1849:64-70.

45. Cardoso AL, Fantinatti BEA, Venturelli NB, Carmello BO, de Oliveira RA, Martins C. Epigenetic DNA modifications are correlated with B chromosomes and sex in the cichlid Astatotilapia latifasciata. Front Genet 2019;10:324.

46. Sivakumar A, Heras J, Schirmer E. Spatial genome organization: from development to disease. Front Cell Dev Biol 2019;7:1-12.

47. Koo D-H, Han F, Birchler JA, Jiang J. Distinct DNA methylation patterns associated with active and inactive centromeres of the maize B chromosome. Genome Res 2011;21:908-914.

48. Navarro-Domínguez B, Ruiz-Ruano FJ, Cabrero J, Corral JM, López-León MD, Sharbel TF, et al. Protein-coding genes in B chromosomes of the grasshopper Eyprepocnemis plorans. Sci Rep 2017;7:45200.

49. Valente GT, Conte MA, Fantinatti BEA, Cabral-de-Mello DC, Carvalho RF, Vicari MR, et al. Origin and evolution of B chromosomes in the cichlid fish Astatotilapia latifasciata based on integrated genomic analyses. Mol Biol Evol 2014; 31:2061-2072.

Address correspondence to:
Roberto Ferreira Artoni, PhD
Programa de Pós-Graduaçáo em Biologia Evolutiva
Laboratório de Genética Evolutiva
Universidade Estadual de Ponta Grossa
Avenida Carlos Cavalcanti, 4748
Ponta Grossa 84030-900
Paraná
Brazil
E-mail: rfartoni@gmail.com

